\title{
Health Survey of Residents Living Near Farm Fields Permitted to Receive Biosolids
}

Sadik Khuder, PhD; Sheryl A. Milz, PhD; Michael Bisesi, PhD; Robert Vincent, PhD; Wendy McNulty, MS; Kevin Czajkowski, PhD

\begin{abstract}
The authors studied the health status of residents living in Wood County, OH, near farm fields that were permitted to receive biosolids. They mailed a health survey to 607 households and received completed surveys from 437 people exposed to biosolids (living on or within 1 mile of the fields where application was permitted) and from 176 people not exposed to biosolids (living more than 1 mile from the fields where application was permitted). The authors allowed for up to 6 surveys per household. Results revealed that some reported health-related symptoms were statistically significantly elevated among the exposed residents, including excessive secretion of tears, abdominal bloating, jaundice, skin ulcer, dehydration, weight loss, and general weakness. The frequency of reported occurrence of bronchitis, upper respiratory infection, and giardiasis were also statistically significantly elevated. The findings suggest an increased risk for certain respiratory, gastrointestinal, and other diseases among residents living near farm fields on which the use of biosolids was permitted. However, further studies are needed to address the limitations cited in this study.
\end{abstract}

KEYWORDS: biosolids, epidemiology, health survey 
Little is known about the health risk associated with Class B biosolids for residents living near the fields undergoing application. These residents are potentially exposed to a wide variety of agents ranging from heavy metals and other hazardous materials in industrial waste to bacteria, viruses, and protozoa in domestic waste. ${ }^{4}$ Notably, there have been anecdotal reports of symptoms and disease among communities surrounding areas where biosolids were applied. ${ }^{5}$

We examined whether an association existed between self-reported health effects of residents living in Wood County, $\mathrm{OH}$, and distance from fields where application of Class B biosolids was permitted.

\section{METHODS}

Wood County has 11 operational wastewater treatment plants (WWTPs). Plants located in the county's 2 largest cities-Bowling Green and Perrysburg-performed the majority of biosolids application for the county. Biosolids application may be performed by splash application, injection, or cake application. The method of application used by each WWTP is determined independently. At the time of the study, Bowling Green used splash application and Perrysburg used cake application. No injection was being performed in Wood County.

We used a clustered cross-sectional survey design, as approved by the Institutional Review Board at the University of Toledo-Health Science Campus. We generated a listing of all households in Wood County by distance from farm fields permitted to receive Class B biosolids, using ArcView software (ArcView 3.2, ESRI, Redlands, CA). To develop this list, we created a GIS shapefile using input from 3 sources: paper plat maps obtained from the Northwest Ohio EPA office; a high-resolution aerial, digital orthophoto mosaic of the county from the Wood County engineer; and a parcel layer (a map that shows the boundaries of each property) from the Wood County auditor. We located the fields where biosolids application was permitted by manually interpreting photos in the digital orthophoto mosaic. In addition, we used the plat descriptions from the 2 other inputs to help locate the permitted fields. We then drew polygons around each field that had been permitted for Class B biosolids application. Using ArcGIS software, we produced a distance buffer zone layer. We calculated and plotted distance buffer zones from the edges of fields where Class B biosolids application was permitted for areas by distance from the nearest field where such application was permitted: on the field, within 1 mile of the field, greater than 1 mile and within 2 miles away, greater than 2 miles and within 3 miles away, greater than 3 and within 4 miles away, greater than 4 and within 5 miles away, and greater than 5 miles away. $^{6}$

We selected households on the basis of their distance from farm fields that were permitted to receive Class B biosolids. We selected all houses located on these fields $(n=193)$. From categories developed on the basis of the house's distance from the fields, we selected a random sample of households off the fields. The categories included distances within 1 mile $(1.61 \mathrm{~km} ; n=203)$ and distances more than 1 mile $(1.61 \mathrm{~km} ; n=211)$, with this sample divided between houses within 2 miles (1.61-3.22 km; $n=108)$ and greater than 2 miles away $(3.22 \mathrm{~km} ; n=103)$. In total, 607 households received the mailed health survey.

The 607 households received mailings that included a cover letter explaining the study, 1 general household questionnaire, 6 human disease questionnaires, and a postagepaid return envelope. The first mailing occurred October 3, 2005, with responses requested by October 14, 2005. The second mailing to nonrespondents was sent October 17, 2005, with responses requested by October 28, 2005. We sent a third and final mailing to the remaining nonrespondents on October 31, 2005, with responses requested by November 11, 2005.

We developed the human disease questionnaire after an extensive literature review. In addition, we used previously validated questions from a study of wastewater workers when appropriate. ${ }^{7}$ We based the questionnaire on symptoms and diseases possibly associated with exposure to agents within biosolids. We included in the questionnaire demographics (age, sex, race, occupation), smoking habits, employment in occupations with exposure to infectious agents (ie, a potentially confounding variable), and the occurrence of specific physician-diagnosed acute and chronic diseases and specific self-reported symptoms.

Individuals designated as exposed lived within 1 mile of a field where application of Class B biosolids was permitted. Individuals designated as unexposed lived more than 1 mile from the nearest such field. Therefore, we based the exposure determination solely on the distance the household was located from a field where application of biosolids was permitted.

\section{Data Analysis}

For the first analysis, we combined the data for individuals living on the field with that of individuals living within 1 mile $(1.61 \mathrm{~km})$ of the field (exposed group), which we compared with the data for individuals living more than 1 mile from the field (unexposed group). To accommodate the clustering of the data at the household level, we used SAS SURVEY procedures (SURVEYFREQ \& SURVEYL$\mathrm{OGISTIC}^{8}$ ). To adjust for differences in the number of surveys received per household, we used survey weights. We defined the weighting factor as the ratio of the number of individuals to the number of households for each group.

We compared demographics and other characteristics of the 2 groups using chi-square analysis. We used logistic regression models to compare the proportion of individuals reporting a particular symptom between the 2 areas. We defined a positive response as an individual symptom reported to occur during the previous 12 months and a negative response as no symptom during the previous 12 months. We 
tested dose-response relations between frequency of reported symptom and exposure using the CochranArmitage test.

We performed additional analyses for the exposed group to determine whether the actual distance of each household from the farm fields where application of Class B biosolids was permitted, on the basis of the GIS determination, had a relationship to the self-reported diseases or symptoms. We also used logistic regression models in these analyses.

\section{RESULTS}

We received 437 surveys from 178 households in the exposed area and 176 from 80 households in the unexposed area. The response rate from the exposed households was $50 \%$ after 3 mailings for the houses on the fields and $42 \%$ after 2 mailings for houses within 1 mile of the fields. The response rate from the unexposed households was $36 \%$ after 1 mailing for houses more than 1 mile from the fields.

The demographic characteristics of the 2 groups are relatively similar (see Table 1). The average age for the exposed area was 41.9 years $(S D=23)$ and for the unexposed area, 41.3 years $(S D=23)$. No significant differences were found between the 2 groups with regard to gender, race, length of time living on the farm, percentage of time each year spent at that address, high-risk occupations, or smoking status.

Table 2 summarizes the symptoms experienced for the previous 12 months for both the exposed group and the unexposed group. Most of the symptoms experienced occurred more often among the exposed group than in the unexposed group. The highest percentage of symptoms, reported among the exposed group, was for headache, cough, sneezing, and sore throat. Symptoms significantly elevated in the exposed group relative to the unexposed group included excessive secretion of tears $(p=.023)$, abdominal bloating $(p=.020)$, jaundice $(p=.012)$, skin ulcers $(p=.035)$, dehydration $(p=$ $.009)$, weight loss $(p=.001)$, and weakness $(p=.043)$. The Cochran-Armitage test revealed significant dose-response relations for excessive secretion of tears, abdominal bloating, and dehydration.

Table 3 summarizes the chronic medical conditions for both the exposed group and the unexposed group. Emphysema, arthritis, and chronic bronchitis occurred more frequently in the exposed group than in the unexposed group, but the difference was statistically significant for emphysema only ( $p=.025)$. Cases of ulcerative colitis, multiple sclerosis, Parkinson's disease, and scleroderma were reported only among the exposed group. However, these differences also were not statistically significant.

Table 4 summarizes the frequency of occurrence of acute disease reported by the exposed group and the unexposed group. We observed significant elevations in the prevalence rates of bronchitis $(p=.022)$, pneumonia $(p=.045)$, upper respiratory infection $(p=.023)$, and giardiasis $(p=.023)$.

Table 5 summarizes results from the logistic regression analyses for the frequency of occurrence of acute disease
Table 1.-Demographic Characteristics of the Study Population

\begin{tabular}{|c|c|c|c|c|c|}
\hline \multirow[b]{2}{*}{ Variable } & \multicolumn{2}{|c|}{$\begin{array}{l}\text { Exposed } \\
(n=437)\end{array}$} & \multicolumn{2}{|c|}{$\begin{array}{l}\text { Unexposed } \\
(n=176)\end{array}$} & \multirow[b]{2}{*}{$p$} \\
\hline & $n$ & $\%$ & $n$ & $\%$ & \\
\hline Age (y) & & & & & .972 \\
\hline$<18$ & 95 & 21.7 & 40 & 22.7 & \\
\hline $18-35$ & 70 & 16.0 & 29 & 16.5 & \\
\hline $36-59$ & 173 & 39.6 & 66 & 37.5 & \\
\hline$\geq 60$ & 99 & 22.7 & 41 & 23.3 & \\
\hline Gender & & & & & 630 \\
\hline Male & 215 & 49.9 & 84 & 47.7 & \\
\hline Female & 216 & 50.1 & 92 & 52.3 & \\
\hline Race & & & & & .062 \\
\hline White & 409 & 95.3 & 174 & 98.9 & \\
\hline Other & 20 & 4.7 & 2 & 1.1 & \\
\hline $\begin{array}{l}\text { Length of time } \\
\text { living on farm (v) }\end{array}$ & & & & & .549 \\
\hline$<5$ & 147 & 34.2 & 57 & 32.8 & \\
\hline $5-10$ & 75 & 17.4 & 37 & 21.2 & \\
\hline $10+$ & 208 & 48.4 & 80 & 46.0 & \\
\hline $\begin{array}{l}\text { Percentage of time } \\
\text { each year living } \\
\text { in the house }\end{array}$ & & & & & .114 \\
\hline$<50$ & 25 & 5.8 & 5 & 2.9 & \\
\hline 100 & 408 & 94.2 & 170 & 97.1 & \\
\hline $\begin{array}{l}\text { High-risk } \\
\text { occupation }^{\mathrm{a}}\end{array}$ & & & & & .726 \\
\hline Yes & 95 & 21.7 & 36 & 20.5 & \\
\hline No & 342 & 78.3 & 140 & 79.6 & \\
\hline Current smoker & & & & & .631 \\
\hline Yes & 57 & 13.4 & 21 & 11.9 & \\
\hline No & 369 & 86.6 & 155 & 88.1 & \\
\hline
\end{tabular}

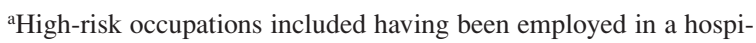
tal, dental clinic, veterinary clinic, long-term care facility, day care center, wastewater treatment facility, or as a waste collector.

and actual distance from the fields where biosolids application was permitted. Negative association with distance was found for bronchitis, pneumonia, upper and lower respiratory infection, cold, giardiasis, and gastroenteritis. However, only the association with bronchitis was statistically significant $(p=.042)$.

Additional analyses of children (aged $<18$ years) only revealed no significant differences between the exposed group and the unexposed group.

\section{COMMENT}

We observed an association between respiratory, gastrointestinal, and general symptoms linked with infectious diseases and residence in homes near farm fields permitted to receive Class $\mathrm{B}$ biosolids. Moreover, we found a significant dose-response relationship for excessive secretion of tears, abdominal bloating, and dehydration. These findings are in agreement with the findings of Lewis et $\mathrm{al}^{9}$ and studies on wastewater treatment workers. ${ }^{7}$ However, they contradict an earlier study from 3 areas in Ohio, in which researchers reported no significant differences in the risk of 


\begin{tabular}{|c|c|c|c|c|c|}
\hline \multirow[b]{2}{*}{ Symptom } & \multicolumn{2}{|c|}{$\begin{array}{l}\text { Exposed } \\
(n=437)\end{array}$} & \multicolumn{2}{|c|}{$\begin{array}{l}\text { Unexposed } \\
(n=176)\end{array}$} & \multirow[b]{2}{*}{$p$} \\
\hline & $n$ & $\%$ & $n$ & $\%$ & \\
\hline Headache & 342 & 80.9 & 133 & 76.9 & .274 \\
\hline Fever & 214 & 50.4 & 90 & 50.6 & .615 \\
\hline $\begin{array}{l}\text { Excessive } \\
\text { secretion } \\
\text { of tears }\end{array}$ & 106 & 25.2 & 28 & 16.5 & .023 \\
\hline Cough & 346 & 81.6 & 133 & 76.9 & .189 \\
\hline Sneezing & 351 & 82.4 & 139 & 79.4 & .395 \\
\hline Sore throat & 310 & 72.4 & 118 & 67.8 & .258 \\
\hline $\begin{array}{l}\text { Chest pain or } \\
\text { discomfort }\end{array}$ & 130 & 30.3 & 48 & 27.8 & .534 \\
\hline $\begin{array}{l}\text { Abdominal } \\
\text { pain }\end{array}$ & 180 & 42.5 & 64 & 37.2 & .239 \\
\hline $\begin{array}{r}\text { Abdominal } \\
\text { bloating }^{\text {a }}\end{array}$ & 150 & 35.9 & 44 & 25.9 & .020 \\
\hline Nausea & 193 & 45.8 & 79 & 45.9 & .985 \\
\hline Vomiting & 153 & 36.3 & 64 & 37.4 & .789 \\
\hline Diarrhea & 273 & 64.5 & 111 & 63.8 & .863 \\
\hline Constipation & 189 & 45.1 & 68 & 39.8 & .236 \\
\hline Jaundice & 33 & 7.9 & 4 & 2.3 & .012 \\
\hline Skin rash & 110 & 26.1 & 34 & 19.8 & .105 \\
\hline $\begin{array}{l}\text { Ulcer on } \\
\text { the skin }\end{array}$ & 36 & 8.5 & 6 & 3.6 & .035 \\
\hline Muscle spasm & 128 & 30.3 & 44 & 25.9 & .281 \\
\hline Chills & 129 & 30.6 & 56 & 32.9 & .573 \\
\hline Dehydration ${ }^{a}$ & 72 & 17.1 & 15 & 8.8 & .009 \\
\hline Loss of appetite & 92 & 21.8 & 41 & 24.0 & .565 \\
\hline Weight loss & 93 & 22.1 & 18 & 10.6 & .001 \\
\hline Insomnia & 197 & 46.6 & 83 & 48.5 & .664 \\
\hline Fatigue & 224 & 53.2 & 96 & 55.5 & .612 \\
\hline Weakness & 143 & 34.1 & 44 & 25.6 & .043 \\
\hline $\begin{array}{l}\text { General ill } \\
\text { feeling }\end{array}$ & 187 & 44.8 & 74 & 43.0 & .686 \\
\hline
\end{tabular}

Note. Italicized $p$ values are significant at .05 .

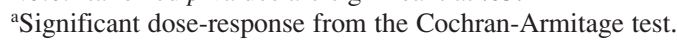

respiratory, gastrointestinal, and general symptoms between sludge-farm residents and control-farm residents. In the Ohio study, the biosolids application rates were low and thus exposure levels may not have been comparable to those in this study. ${ }^{10}$

The finding of significantly elevated risk for bronchitis and upper respiratory infection among residents living near farm fields where the use of biosolids was permitted agrees with other published findings. A significantly increased risk for chronic bronchitis and pneumonia has been reported for sewage workers, ${ }^{11-14}$ and possible causative agents include viruses, other microorganisms, and endotoxins. ${ }^{14-16}$ Smit et $\mathrm{al}^{17}$ even reported a dose-response relationship between endotoxin exposures and flu-like symptoms. Chemical irritants such as lime, ammonia, and alkyl amines also may contribute to broncho-obstructive and inflammatory responses. ${ }^{10}$ In addition, increased rates of symptoms-including respiratory problems, eye irritation, nausea, and weakness-
Table 3.-Distribution of Chronic Diseases of Residents Living Within 1 Mile of Farm Fields Where Biosolids Application Was Permitted (Exposed) and Residents Living $>1$ Mile From Such Fields (Unexposed)

\begin{tabular}{|c|c|c|c|c|c|}
\hline \multirow[b]{2}{*}{ Disease/condition } & \multicolumn{2}{|c|}{$\begin{array}{c}\text { Exposed } \\
(n=437)\end{array}$} & \multicolumn{2}{|c|}{$\begin{array}{l}\text { Unexposed } \\
(n=176)\end{array}$} & \multirow[b]{2}{*}{$p$} \\
\hline & $n$ & $\%$ & $n$ & $\%$ & \\
\hline Asthma & 52 & 12.3 & 17 & 9.9 & .406 \\
\hline Emphysema & 12 & 2.9 & 1 & 0.6 & .025 \\
\hline Crohn's disease & 1 & 0.2 & 1 & 0.6 & .582 \\
\hline Migraine headache & 39 & 9.3 & 16 & 9.4 & .956 \\
\hline Ulcerative colitis & 4 & 1.0 & 0 & 0.0 & .099 \\
\hline Chronic bronchitis & 26 & 6.2 & 5 & 2.9 & .066 \\
\hline Irritable bowel syndrome & 30 & 7.1 & 16 & 9.4 & .380 \\
\hline Allergies & 129 & 30.5 & 50 & 29.2 & .762 \\
\hline Multiple sclerosis & 5 & 1.2 & 0 & 0.0 & .065 \\
\hline Parkinson's disease & 4 & 1.0 & 0 & 0.0 & .099 \\
\hline Scleroderma & 3 & 0.7 & 0 & 0.0 & .153 \\
\hline Skin disease & 22 & 5.2 & 10 & 5.9 & .752 \\
\hline Poliomyelitis & 3 & 0.7 & 2 & 1.2 & .619 \\
\hline Autism & 3 & 0.7 & 0 & 0.0 & .153 \\
\hline Skin cancer & 9 & 2.1 & 4 & 2.3 & .868 \\
\hline Arthritis/osteoarthritis & 12 & 2.8 & 1 & 0.6 & .057 \\
\hline
\end{tabular}

Note. The italicized $p$ value is significant at .05 .

have been reported among residents living near a large-scale swine farm. ${ }^{18}$ However, investigators evaluating livestock waste (which is used as a natural fertilizer) reported that less than $0.01 \%$ of aerosolized microbes are viable, ${ }^{19}$ possibly indicating that exposure to aerosolized biosolids is unlikely to cause infections.

Rates of reported gastrointestinal symptoms, such as abdominal bloating and giardiasis, were significantly elevated among the exposed residents in this study. This finding is in agreement with several studies that have reported that gastrointestinal symptoms are elevated among sewage workers. 7,14,15,20,21 In addition, Heap and McCulloch ${ }^{22}$ reported 3 cases of sewage workers who appeared to have become infected with giardiasis after being exposed to raw sewage while not wearing personal protective equipment.

The increased risk for ulcer on the skin (and to some extent, skin rash) among exposed residents is expected. Lundholm and Rylander ${ }^{23}$ reported that sewage treatment plant workers exhibited a higher proportion of skin disorders than a control group. Residents living near fields where biosolids are applied potentially are exposed to a wide range of pollutants, ranging from chemicals such as heavy metals to various infectious agents, parasites, and noninfectious bacterial agents. Lewis and $\mathrm{Gattie}^{2}$ suggested that the potential exists for Staphylococcus aureus to be transmitted from land-applied biosolids. S. aureus is the suspected agent for a wide variety of human infections, including skin infections and pneumonia. ${ }^{24}$

Newly applied biosolids contain microorganisms. As the biosolids dry, some microorganisms die and others become 


\begin{tabular}{|c|c|c|c|c|c|}
\hline \multicolumn{6}{|c|}{$\begin{array}{l}\text { Table 4.-Distribution of Acute Diseases Among } \\
\text { Residents Living Within } 1 \text { Mile of Farm Fields } \\
\text { Where Application of Biosolids Was Permitted } \\
\text { (Exposed) and Residents Living > } 1 \text { Mile From } \\
\text { Such Fields (Unexposed) }\end{array}$} \\
\hline \multirow[b]{2}{*}{ Disease/condition } & \multicolumn{2}{|c|}{$\begin{array}{l}\text { Exposed } \\
(n=437)\end{array}$} & \multicolumn{2}{|c|}{$\begin{array}{l}\text { Unexposed } \\
(n=176)\end{array}$} & \multirow[b]{2}{*}{$p$} \\
\hline & $n$ & $\%$ & $n$ & $\%$ & \\
\hline Leptospirosis & 1 & 0.2 & 2 & 1.1 & .281 \\
\hline Salmonellosis & 2 & 0.3 & 2 & 1.1 & .445 \\
\hline Shigellosis & 2 & 0.3 & 2 & 1.1 & .445 \\
\hline Typhoid fecer & 2 & 0.3 & 2 & 1.1 & .445 \\
\hline Hepatitis A & 2 & 0.3 & 2 & 1.1 & .445 \\
\hline Poliomyelitis & 1 & 0.2 & 2 & 1.1 & .281 \\
\hline Amoebiasis & 1 & 0.2 & 2 & 1.1 & .281 \\
\hline Bronchitis & 69 & 16.3 & 17 & 9.7 & .022 \\
\hline Pneumonia & 23 & 5.5 & 4 & 2.3 & .045 \\
\hline $\begin{array}{l}\text { Upper respiratory } \\
\text { infection }\end{array}$ & 115 & 27.3 & 33 & 18.9 & .023 \\
\hline $\begin{array}{l}\text { Lower respiratory } \\
\text { infection }\end{array}$ & 25 & 6.0 & 6 & 3.4 & .157 \\
\hline Cold & 182 & 43.4 & 64 & 36.8 & .131 \\
\hline Giardiasis & 12 & 2.9 & 1 & 0.6 & .023 \\
\hline Gastroenteritis & 37 & 8.8 & 12 & 6.9 & .415 \\
\hline
\end{tabular}

Note. Italicized $p$ values are significant at .05 .

more concentrated along with chemical agents present. The concentrated form of biosolids may be more irritating after dermal contact and inhalation. ${ }^{9}$ We found an elevation of excessive secretion of tears among exposed residents, which could be explained by the presence of ammonia in the concentrated, dried biosolids.

Other symptoms significantly elevated in the exposed group were increased weight loss and general weakness. An increased risk for central nervous symptoms such as unusual tiredness has been reported among sewage workers ${ }^{15,17}$ and among persons in an organic dust environment. ${ }^{25}$

We observed an increased risk for arthritis and osteoarthritis in this study. Likewise, Rylander ${ }^{14}$ reported an increased risk of joint pain among sewage workers. Thorn et $\mathrm{al}^{26}$ attributed this increased risk of joint pain to an inflammatory/systemic response among sewage workers. Possible causative agents have been reported as viruses such as Norwalk virus, other microorganisms, and endotoxins. ${ }^{14-16}$

Cases of ulcerative colitis (3 cases), multiple sclerosis (5 cases), Parkinson's disease (4 cases), and scleroderma (3 cases) were reported in the exposed area. Although no cases of these diseases were reported in the unexposed area, the difference between the 2 areas in the number of multiple sclerosis cases approached statistical significance $(p=.065)$. The lack of statistical significance may be attributed to our small sample size.

The prevalence of multiple sclerosis $(1,171$ per 100,000 population) found in this study is significantly elevated $(p=.001)$ relative to the reported prevalence of 85 per 100,000 for the noninstitutionalized population in the United States. ${ }^{27}$ However, a larger sample should be studied to
Table 5.-Logistic Regression Results for Acute Diseases According to Actual Distance From Farm Fields Where Application of Biosolids Was Permitted

\begin{tabular}{lrrrr}
\hline \hline Disease/condition & $\beta$ & $S E$ & $\chi^{2}$ & $p$ \\
\hline Leptospirosis & .84 & 0.62 & 1.83 & .175 \\
Salmonellosis & .45 & 0.51 & 0.77 & .381 \\
Shigellosis & .45 & 0.51 & 0.77 & .381 \\
Typhoid fever & .65 & 0.52 & 1.58 & .208 \\
Hepatitis A & .50 & 0.51 & 0.95 & .331 \\
Poliomyelitis & .84 & 0.62 & 1.84 & .175 \\
Amoebiasis & .84 & 0.62 & 1.84 & .175 \\
Bronchitis & -.29 & 0.15 & 4.12 & .042 \\
Pneumonia & -.40 & 0.27 & 2.28 & .131 \\
Upper respiratory & -.17 & 0.11 & 2.25 & .134 \\
$\quad$ infection & & & & \\
Lower respiratory & -.22 & 0.23 & 0.92 & .337 \\
$\quad$ infection & & & & \\
Cold & -.09 & 0.09 & 0.92 & .337 \\
Giardiasis & -.70 & 0.47 & 2.29 & .130 \\
Gastroenteritis & -.12 & 0.17 & 0.47 & .491 \\
&
\end{tabular}

Note. The italicized $p$ value is significant at .05 . For the $\chi^{2}$ values: $d f=1, n$ (exposed) $=437, n$ (unexposed $)=176$.

verify whether the difference is real or just occurred by chance. A variety of infectious agents have been postulated as important in the etiology of multiple sclerosis, but a causal association has not been demonstrated convincingly for any infectious agent. ${ }^{26-29}$ An increased risk for multiple sclerosis is likely to involve a combination of genetic susceptibility and environmental exposures. ${ }^{30}$ In addition, a clustering of multiple sclerosis in Galion, $\mathrm{OH}$, from 1982 to 1985 was attributed to an excess concentration of heavymetal wastes, especially cadmium and chromium, in sewage and river water. ${ }^{31}$ Kraut et $\mathrm{al}^{32}$ reported that neurotoxic effects can be caused by chemical exposures from sewage.

There are several limitations with this study. First, the results were based on self-reporting of symptoms and diseases. It is possible that individuals living near fields where biosolids are applied and who are exposed to odors and other biosolids debris may be more prone to report diseases and symptoms. Odors and other nontoxic emissions from biosolids could trigger an overreporting of certain symptoms among residents. In a study in North Carolina, residents of areas near swine farms reported significantly more tension, depression, anger, fatigue, and confusion at the time when odors were present than did a control group of unexposed persons. ${ }^{33}$ In addition, retrospective studies indicate that symptom prevalence near polluted sites can significantly increase when the ambient air is odorous. ${ }^{34}$ Finally, irritant symptoms coupled with a fear of toxicity may produce a state of autonomic arousal leading to a panic attack. This panic attack can then progress to a conditioned response in which subsequent exposure could produce panic attacks automatically because of a behavioral sensitization to odorants. ${ }^{35}$ Unfortunately, we collected no information on odors in this study. 
Second, recall bias is possible, especially with regard to the frequency of reported symptoms over a long period of time. We made the assumption that all of the symptoms and diseases included in the questionnaires are potentially related to biosolids. However, certain symptoms (such as insomnia and fatigue) may be related to systemic factors and are less likely to be related to biosolids. In this study, almost $50 \%$ of both the exposed and unexposed groups reported insomnia and fatigue symptoms, suggesting a nondifferential recall bias in the exposed group.

Third, the overall response rate for this study was less than $50 \%$. However, a low response rate is not unusual in studies conducted in rural areas. ${ }^{36}$ In addition, despite a lower response rate for postal questionnaires compared with interviews, Morgaine et al ${ }^{37}$ reported that the 2 methods produced similar health data. Therefore, even with a low response rate the respondents' health data are assumed to be similar to that not collected from nonrespondents. Residents who are more concerned, have symptoms, or are otherwise affected by biosolids applications also may be more likely to respond. We offered a monetary reward to all responding households in an attempt to minimize this problem. In addition, the households were not informed of the biosolids focus of the study (their letter of explanation stated that the study was on the health status of Wood County residents) and were also questioned on their knowledge of chemical fertilizer application, natural fertilizer (animal waste) application, and biosolids application.

Fourth, residents who responded to the first mailing of the survey possibly were more or less healthy than those who responded to the second or third mailings. We did not record the date of response for any of the returned surveys and therefore, could not analyze the data to confirm or deny that such a limitation existed.

Fifth, exposure misclassification is a definite concern with this study. We classified the exposed group solely on the basis of the household being located within 1 mile from a field where biosolids application was permitted. However, exposure could exist beyond the 1-mile boundary. Moreover, at the time of the study, we did not know the date of last application, cumulative amount of biosolids application, direction of the household from the permitted fields, and meteorological conditions. We plan additional analyses using the date of last application, cumulative amount of application, and direction from the fields once the information has been collected. Researchers in future studies can evaluate the effect of prevailing winds on the possible dispersion of biosolids to households (using the information on the location of the household and its relative direction from the fields).

Finally, we compared our findings with those in the literature concerning wastewater workers. However, exposure characteristics of wastewater workers would presumably differ from those in residents living near farm fields where biosolids were applied. For example, potential exposure to airborne contaminants from wet sewage, more likely to occur among wastewater workers, is different from the po- tential exposure to airborne contaminants from dry biosolids, more likely to occur among residents living near farm fields where biosolids were applied, resulting in differing routes of exposure. In addition, many of the risks to individuals living near farm fields where biosolids were applied are chronic and may be evident only after long-term exposure. Such effects are difficult to measure and relate to exposure from these fields.

In conclusion, our findings suggest an increased risk for certain respiratory, gastrointestinal, and other diseases among residents living near farm fields where the application of biosolids was permitted. Moreover, the reported occurrence of certain chronic diseases, such as multiple sclerosis, were elevated in the exposed group. Further studies are needed to determine the relation between time from last application of biosolids and reported health effects as well as to address cited limitations.

$$
* * * * * * * * * *
$$

Requests for reprints should be sent to Dr Sheryl Milz, University of Toledo, DPHHS, 3000 Arlington Ave., Toledo, OH 43614, USA.

E-mail: sheryl.milz@utoledo.edu

$$
* * * * * * * * * *
$$

\section{References}

1. National Institute for Occupational Safety and Health. Guidance for Controlling Risks to Workers Exposed to Class B Biosolids. Washington, DC: US Department of Health and Human Services, Centers for Disease Control and Prevention; 2006. Publication No. 2002-149.

2. Lewis DL, Gattie DK. Pathogen risks from applying sewage sludge to land. Environ Sci Technol. 2002;36:287A-293A.

3. US Environmental Protection Agency. Biosolids Generation, Use, and Disposal in the United States. Washington, DC: Office of Solid Waste and Emergency Response; 1999. EPA530-R-99-009.

4. McCunney RJ. Health effects of work at waste water treatment plants: a review of the literature with guidelines for medical surveillance. Am J Ind Med. 1986;9:271-279.

5. Evanylo GK. Agricultural Land Application of Biosolids in Virginia: Risks and Concerns. Blacksburg, VA: Department of Crop and Soil Environmental Sciences, Virginia Polytechnic Institute and State University; 1999. Publication 432-304.

6. McNulty WS. The Creation of a GIS Database and the Determination of Sludge's Spectral Signature in an Agricultural Setting [master's thesis]. Bowling Green, OH: Bowling Green State University, Department of Geology; 2005.

7. Khuder SA, Arthur T, Bisesi MS, Schaub EA. Prevalence of infectious diseases and associated symptoms in wastewater treatment workers. Am J Ind Med. 1998;33:571-577.

8. SAS Institute, Inc. Introduction to survey sampling and analysis procedures. In: SAS/STAT 9.1 User's Guide. Cary, NC: SAS Institute; 2004:159-169.

9. Lewis DL, Gattie DK, Novak ME, Sanchez S, Pumphrey C. Interactions of pathogens and irritant chemical in land-applied sewage sludges (biosolids). BMC Public Health. 2002;2:11.

10. Dorn CR, Reddy CS, Lamphere DN, Gaeuman JV, Lanese R. Municipal sewage sludge application on Ohio farms: health effects. Environ Res. 1985;38:332-359.

11. Nethercott JR, Holness DL. Health status of a group of sewage treatment workers in Toronto, Canada. Am Ind Hyg Assoc J. 1988;49: 346-350.

12. Zuskin E, Mustajbegovic J, Schachter EN. Respiratory function in sewage workers. Am J Ind Med. 1993;23:751-761.

13. Friis L, Norback D, Edling C. Self-reported asthma and respiratory symptoms in sewage workers. J Occup Health. 1999;41:87-90. 
14. Rylander R. Health effects among workers in sewage treatment plants. Occup Environ Med. 1999;56:354-357.

15. Clark CS. Potential and actual biological related health risks of wastewater industry employment. J Water Pollut Contr Fed. 1987;59: 999-1008.

16. Melbostad E, Eduard W, Skogstad A, et al. Exposure to bacterial aerosols and work-related symptoms in sewage workers. Am J Ind Med. 1994;25:59-63.

17. Smit LAM, Spaan S, Heederik D. Endotoxin exposure and symptoms in wastewater treatment workers. Am J Ind Med. 2005;48:30-39.

18. Thu K, Donham K, Ziegenhorn R, et al. A control study of the physical and mental health of residents living near a large-scale swine operation. J Agric Safety Health. 1997;3:13-26.

19. Kiekaefer MS, Donham KJ, Whitten P, Thorne PS. Cross-sectional studies of airborne microbial populations and environment in swine buildings: implications for workers and animal health. Ann Agric Environ Med. 1995;2:37-44.

20. Scarlett-Kranz JM, Babish JG, Strickland D, Lisk DJ. Health among municipal sewage and water treatment workers. Toxicol Ind Health. 1987:3:311-319.

21. Friis L, Agreus L, Edling C. Abdominal symptoms among sewage workers. Occup Med. 1998;48:251-253

22. Heap BJ, McCulloch MLB. Giardiasis and occupational risk in sewage workers. Lancet. 1991;338:1152.

23. Lundholm M, Rylander R. Work related symptoms among sewage workers. Br J Ind Med. 1983;40:325-329.

24. Waldvogel FA. Staphylococcus aureus. In: Mandell GL, Bennett JE, Dolin R, eds. Principles and Practices of Infections Diseases, 5th ed. Philadelphia, PA: Churchill Livingstone; 2000:2069-2091.

25. Rylander R. Endotoxins in the environment-a criteria document. Int J Occup Environ Health. 1997;3:S1-S48.

26. Thorn J, Beijer L, Rylander R. Work related symptoms among sewage workers: a nationwide survey in Sweden. Occup Environ Med. 2002;59:562-566.
27. Noonan CW, Kathman SJ, White MC. Prevalence estimates for MS in the United States and evidence of an increasing trend for women. Neurology. 2002;58:136-138.

28. Marrie RA, Wolfson C, Sturkenboom MCJM, et al. Multiple sclerosis and antecedent infections: a case-control study. Neurology. 2000;54:2307-2310.

29. Murray J. Infection as a cause of multiple sclerosis. Br Med J. 2002 325:1128.

30. Willer CJ, Ebers GC. Susceptibility to multiple sclerosis: interplay between genes and environment. Curr Opin Neurol. 2000;13. 241-247.

31. Ingalls TH, Huguenin I, Ghent T. Clustering of multiple sclerosis in Galion, Ohio, 1982-1985. Am J Forensic Med Pathol. 1989;10: 213-215.

32. Kraut A, Lilis R, Marcus M, Valciukas JA, Wolff MS, Landrigan PJ. Neurotoxic effects of solvent exposure on sewage treatment workers. Arch Environ Health. 1988;43:263-268.

33. Schiffman SS, Saltely-Miller EA, Suggs MS, Graham BG. The effect of environmental odors emanating from commercial swine operations on the mood of nearby residents. Brain Res Bull. 1995;37: 369-375.

34. Shusterman DJ, Liscomb J, Neutra R, Satin K. Symptom prevalence and odor-worry interaction near hazardous waste sites. Environ Health Perspect. 1991;94:25-30.

35. Shusterman D, Balmer J, Cone J. Behavioral sensitization to irritants/odorants after acute overexposures. J Occup Med. 1988;30:565-567.

36. Tarone RE, Alavanja MCR, Zahm SH, et al. The Agricultural Health Study: factors affecting completion and return of self-administered questionnaires in a large prospective cohort study of pesticide applicators. Am J Ind Med. 1997;31:233-242.

37. Morgaine KC, Firth HM, Herbison GP, Feyer AM, McBride DI. Obtaining health information from farmers: interviews versus postal questionnaires in a New Zealand case study. Ann Agric Environ Med. $2005 ; 12: 223-228$.

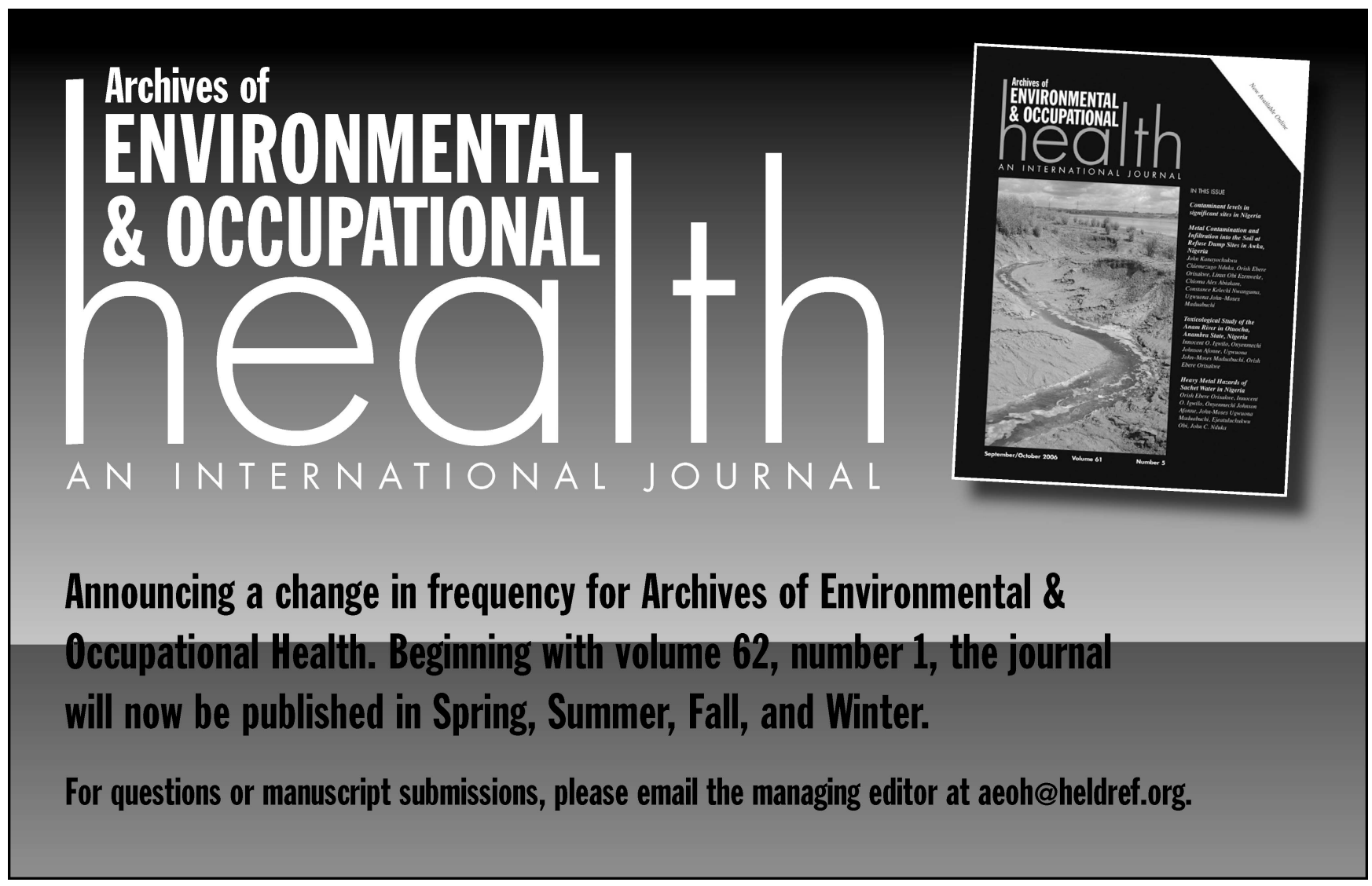

